\section{Dubravka Botica}

\section{Danko Šourek}

Dubravka Botica

Danko Šourek

Odsjek za povijest umjetnosti Filozofski fakultet Sveučilišta u Zagrebu

Izvorni znanstveni rad/Original scientific paper

Predan/Received: 15. 09. 2014

$726.591(497.5$ Pokupsko)

DOI:

http://dx.doi.org/10.17018/portal.2014.12

\section{Oltari u župnoj crkvi sv. Ladislava u Pokupskom - prilog tipologiji arhitekture oltara u XVIII. stoljeću}

SAŽETAK: Ansambl glavnoga te bočnih oltara posvećenih sv. Mariji i sv. Josipu (1739.) u svetištu i prostoru svođenoga slavoluka župne crkve u Pokupskom, plijeni pozornost vrsnoćom umjetničke zamisli kao i neuobičajenim ikonografskim programom. Cjelina, kojoj valja pribrojiti i propovjedaonicu, te skulpture oltara Sv. Križa, dio je velike narudžbe zagrebačkoga biskupa Jurja Branjuga koji je u Pokupskom između 1736. i 1739. godine dao podići novu crkvu, posvećenu osnivaču biskupije sv. Ladislavu kralju. Oltari, djelo drvorezbarske radionice koja je pod biskupovim pokroviteljstvom djelovala na zagrebačkom Kaptolu u prvoj polovici XVIII. stoljeća, arhitektonskim rješenjima i inovativnim ornamentalnim repertoarom suvremenu produkciju sjeverozapadne Hrvatske povezuju sa srednjoeuropskom umjetničkom tradicijom, a odjek pronalaze u ostvarenjima drugih zagrebačkih umjetnika, poput Josipa Weinachta, Antuna Reinera i Antuna Franje Risnera. Ikonografski aspekti glavnoga oltara nastavak su pak specifične ikonografije sv. Ladislava kralja, razvijene u krugu kaptolskih naručitelja potkraj XVII. i početkom XVIII. stoljeća.

KıJUČNe RIJEČI: Pokupsko, oltar sv. Ladislava, oltari sv. Josipa i Marije, biskup Branjug, "Branjugova drvorezbarska radionica“, arhitektura oltara
$\check{Z}$ upna crkva sv. Ladislava u Pokupskom jedna je od najznačajnijih cjelina barokne umjetnosti u kontinentalnoj Hrvatskoj. Upravo je u Pokupskom prvi put ostvarena važna novina četverolisnoga tipa tlocrta koja će snažno obilježiti naše graditeljstvo XVIII. stoljeća, a na njega će bitno utjecati i načini svođenja, krivulje zidnoga plašta, svođeni slavoluk te druga arhitektonska rješenja s kojima se ovdje susrećemo. ${ }^{1}$ Crkva u Pokupskom, rezultat visoke narudžbe zagrebačkoga biskupa Jurja Branjuga (Zagorska Sela, 1677.-Zagreb, 1748.; biskup 1723.-1748.) u kojoj arhitektura tvori cjelinu s unutarnjom opremom, važna je i kao zanimljiv primjer baroknoga Gesamkunstwerka u našoj umjetničkoj baštini. ${ }^{2}$ Kao i inovativna zamisao same arhitekture, kvalitetom zamisli ističu se i projekti glavnoga oltara te oltara sv. Marije i sv. Josipa, povezanih $\mathrm{s}$ radionicom koja je upravo pod Branjugovim pokroviteljstvom djelovala na zagrebačkom Kaptolu. ${ }^{3}$ Štoviše, neke je novìne prisutne na tim oltarima moguće posredno povezati is utjecajima stranih graditeljskih radionica koje su u djelo provodile ambicioznu biskupovu narudžbu. Istodobno, odabirom udaljenoga mjesta, gotovo na tromeđi Katedralnoga, Gorskoga i Goričkoga arhiđakonata, nadomak ruševina grada Steničnjaka - pretpostavljenoga mjesta rođenja osnivača Zagrebačke biskupije, sv. Ladislava kralja - kao i razrađenim ikonografskim programom monumentalnoga glavnoga oltara, ta biskupska narudžba odražava povijesne težnje hrvatskih staleža koje su, još od kraja XVII. stoljeća, uporište tražile u historiografskim djelima Jurja Ratkaja i Pavla Rittera Vitezovića.

Cilj ovoga rada je razmotriti upravo najvrjedniji dio opreme crkve sv. Ladislava - ansambl glavnoga i bočnih oltara posvećenih sv. Mariji i sv. Josipu (1739.) - te naznačiti njihovo mjesto u bogatom korpusu altaristike XVIII. stoljeća na području sjeverozapadne Hrvatske. Također, osvrnut ćemo se i na ikonografske osobitosti glavnoga oltara, kao i cjelokupne narudžbe, prema kojima ta crkva zauzima 


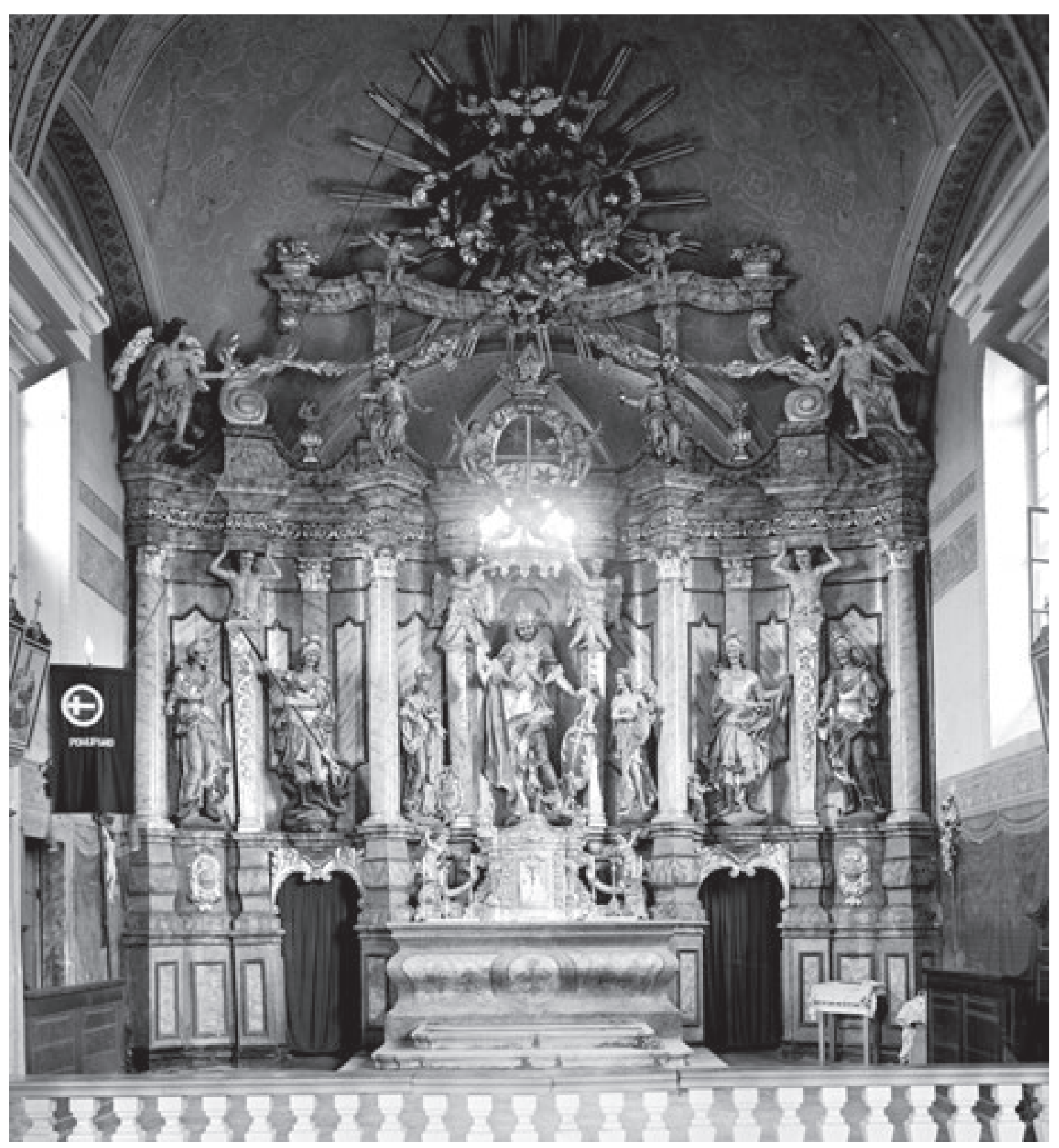

1. Drvorezbarska radionica biskupa Jurja Branjuga, Glavni oltar, 1739., Pokupsko, župna crkva sv. Ladislava (Uznesenja Marijina). Izvor: Schneiderov fotografski arhiv Hrvatske akademije znanosti i umjetnosti (br. 1803).

Woodcarving workshop of Bishop Juraj Branjug, main altar, 1739, Pokupsko, Parish Church of St. Ladislaus (the Assumption of Mary). Source: Schneider's Photo Archive of the Croatian Academy of Sciences and Arts (no. 1803)

posebno mjesto u hrvatskoj umjetničkoj i kulturnoj baštini. Kako je župna crkva u Pokupskom teško stradala u vrijeme Domovinskoga rata, osobito u granatiranju tijekom listopada i studenoga 1991. godine, njezina je oprema bila privremeno uklonjena. ${ }^{4}$ Nakon dugotrajne obnove građevine, sada se kraju privodi i obnova njezinih oltara i propovjedaonices te se dijelovi monumentalnoga glavnoga oltara nakon više od dvadeset godina vraćaju u ambijent za koji su nastali. Ponovno uspostavljanje izvorne slike svetišta, koju će uz glavni upotpuniti i oltari posvećeni sv.
Mariji i sv. Josipu, smješteni unutar svođenoga slavoluka, povod je za ovaj rad.

\section{Gradnja crkve i biskupska narudžba}

Tijekom baroknoga razdoblja visoki je kler, uz plemstvo i crkvene redove, bio najvažniji naručitelj umjetničkih i graditeljskih ostvarenja u kontinentalnoj Hrvatskoj. Pri tome se osobito ističu zagrebački biskupi koji su, uz širok raspon kulturnih veza, rapolagali znatnim posjedima i sredstvima te bili u mogućnosti angažirati kvalitetne 
umjetnike. Kako su banovi, kao i drugi obnašatelji svjetovne vlasti, u sferi likovnih umjetnosti radije sudjelovali kao privatni naručitelji, upravo su zagrebački biskupi (s drugim državničkim prerogativima) na sebe preuzeli i određene aspekte naručiteljstva, motiviranoga željom za afirmacijom povijesne državnosti hrvatskih zemalja. Oni su se prije svega zasnivali na specifičnoj i razrađenoj inačici ikonografije ugarskoga kralja sv. Ladislava (Poljska, o. 1040. - Nitra, 1095.; vladao 1077.-1095.; kanoniziran 1192.), osnivača Zagrebačke biskupije (1094.), ali i važne povijesne spone koja je preko svoje sestre Jelene (0. 1050. - 1091.), udovice kralja Dmitra Zvonimira (vladao 1075.1089.), osiguravala vezu s baštinom drevnoga hrvatskoga kraljevstva. Vjerojatno je najpoznatiji primjer toga ikonografskoga programa ciklus slika ljubljanskoga slikara Ivana Eisenharta (oko 169o.) koji je nekoć, u sjevernoj apsidi zagrebačke katedrale, krasio oltar sv. Ladislava s kraja XVII. stoljeća. ${ }^{6}$ Četiri desetljeća mlađu, crkvu u Pokupskom moguće je pak - s obzirom na njezin već spomenuti karakter zbirnoga umjetničkoga djela (Gesamkunstwerk) - označiti kao najobuhvatniji likovni umjetnički izraz iste tematike svojstvene kaptolskim naručiteljima.7

Kako je Pokupsko bilo jedno od vlastelinstava u posjedu zagrebačkih biskupa, ${ }^{8}$ gradnju i opremanje nove župne crkve nakon prestanka neposredne osmanske opasnosti potaknuo je i proveo upravo biskup Juraj Branjug. Crkva u Pokupskom zauzimala je osobito mjesto među brojnim Branjugovim narudžbama kojima je zaista zaslužio epitet „biskupa graditelja“.9 Na nesvakidašnji karakter biskupovih naručiteljskih ambicija upućuje već i podatak kako je prethodna crkva na istome mjestu, iako drvena, bila $u$ tako dobrom stanju da je nakon uklanjanja (1736.) preseljena u obližnji Šišinec u kojemu je stajala sve do izgradnje tamošnje nove župne crkve 1767 . godine. ${ }^{10}$ Poticaje za gradnju nove crkve u Pokupskom (1736.-1739.) ne treba dakle tražiti u uobičajenim razlozima, poput lošega stanja i trošnosti prethodne građevine, nego u želji za realizacijom jasno definiranoga naručiteljskoga programa, odnosno concetta. O osnovnom sadržaju toga programa ponajbolje pak svjedoči činjenica promjene titulara novosagrađene župne crkve, koji je sa sv. Marte prešao upravo na sv. Ladislava kralja.

Školovan na sveučilištima u Beču i Bologni te izuzetno sklon umjetnosti," Juraj Branjug očito je bio dobro upućen ne samo u važnost Ladislavova kulta za zagrebačku crkvu, nego i u njegovo šire značenje za politički razjedinjeni prostor Trojedne kraljevine te ga je u Pokupskom odlučio potvrditi vlastitom graditeljskom i kiparskom narudžbom.

Kult osnivača Zagrebačke biskupije, prisutan još u srednjem vijeku, dobiva novu snagu potkraj XVII. i početkom XVIII. stoljeća. To je odraz širega poslijetridentskoga povratka »na izvore« (lat. ad fontes) mjesne Crkve. ${ }^{12} \mathrm{Na}$ temelju pisanja suvremenih historiografa, osobito Jurja Ratkaja Velikotaborskoga (Veliki Tabor, 1612. - Zagreb,
1666.) i njegova djela Memoria regum et banorum regnorum Dalmatice, Croatice et Sclavonice (Spomen na kraljeve i banove kraljevstava Dalmacije, Hrvatske i Slavonije, Beč, 1652.) te, poslije, svestranoga polihistora Pavla Rittera Vitezovća (Senj, 1652. - Beč, 1713.), oblikuje se novo tumačenje uloge kralja Ladislava. U Vitezovićevoj raspravi naslovljenoj Natales Divo Ladislavo Regi Sclavonice Apostolo Restituti (Oslobođeno rodoslovlje sv. Ladislava kralja, apostola Slavonije, Zagreb, 1704.) istaknuto je Ladislavovo domaće, hrvatsko podrijetlo, a važna uloga namijenjena je i njegovoj sestri Jeleni. Njezinim je posredovanjem na ispražnjeno hrvatsko prijestolje stupila mađarska dinastija Arpadovića, a Hrvatska je time ušla u državni savez koji je u Branjugovo vrijeme trajao i dulje od šest stotina godina. Isticanjem te činjenice nastojala se opravdati težnja za boljim položajem hrvatskih zemalja $u$ vrijeme iscrtavanja novih granica i novoga uređenja nakon uspješnih ratova s Osmanlijama. ${ }^{13}$ Likovno ostvarenje te tematike zatječemo i - zemljopisno daleko od Zagreba - na svodnoj fresci glavne dvorane Ilirsko-ugarskoga kolegija u Bologni koji, kao mjesto školovanja domaće intelektualne elite, posebice klera, zapravo pripada zagrebačkom kulturnom krugu. Vrijedi istaknuti kako je ta freska s prikazom kralja Ladislava i kraljice Jelene izvedena upravo u vrijeme (oko 1700.) kad je u Bolonjskom kolegiju kao pitomac Zagrebačkoga kaptola boravio Juraj Branjug. ${ }^{14}$ Malo prije (oko 1690.) nastaje i već spomenuti ciklus štafelajnih slika za krilni oltar sv. Ladislava u zagrebačkoj katedrali, na kojem su tradicionalni i poslijetridentski aspekti svečeve hagiografije protkani posve suvremenim težnjama za ponovnim ujedinjenjem hrvatskih zemalja (prizor velikaša s grbovima Hrvatske, Slavonije i Dalmacije pred kraljem Ladislavom i kraljicom Jelenom). S obzirom na odabir mjesta i promjenu titulara nove crkve u Pokupskom, moguće je zaključiti kako je na Branjugov concetto, uz prijašnje primjere, odlučujuće utjecala upravo Vitezovićeva rasprava o hrvatskom podrijetlu kralja Ladislava, koja kraljevo rođenje smješta u burg Steničnjak, smješten jugozapadno od Pokupskoga, na desnoj obali Kupe. ${ }^{.5}$ Podizanjem nove crkve s promijenjenim titularom te angažmanom kvalitetnih stranih radionica, biskup Branjug očito je želio simbolički obilježiti mjesto (župu/povijesni topos) kraljeva rođenja.

\section{Oltar sv. Ladislava - opis}

U župnoj crkvi u Pokupskom ostvaren je prostor visoke scenične kvalitete. Centralni brod svođen visokom češkom kapom „širi se“ u bočne kapele i prostor svođenoga slavoluka zaobljenih obrisa, a pojasnice uokviruju pogled na svetište također svođeno češkom kapom, na kojoj je izveden motivikom izuzetno bogat ciklus štukatura. ${ }^{16}$ Slijedeći odredbe Tridentskoga sabora (1545-1563.) o nužnosti neometanoga pogleda na glavni oltar, arhitekti baroknoga razdoblja kao dominantnu prostornu sliku nerijetko u oblikovanju prostora, ali i u arhitekturi oltara, primje- 


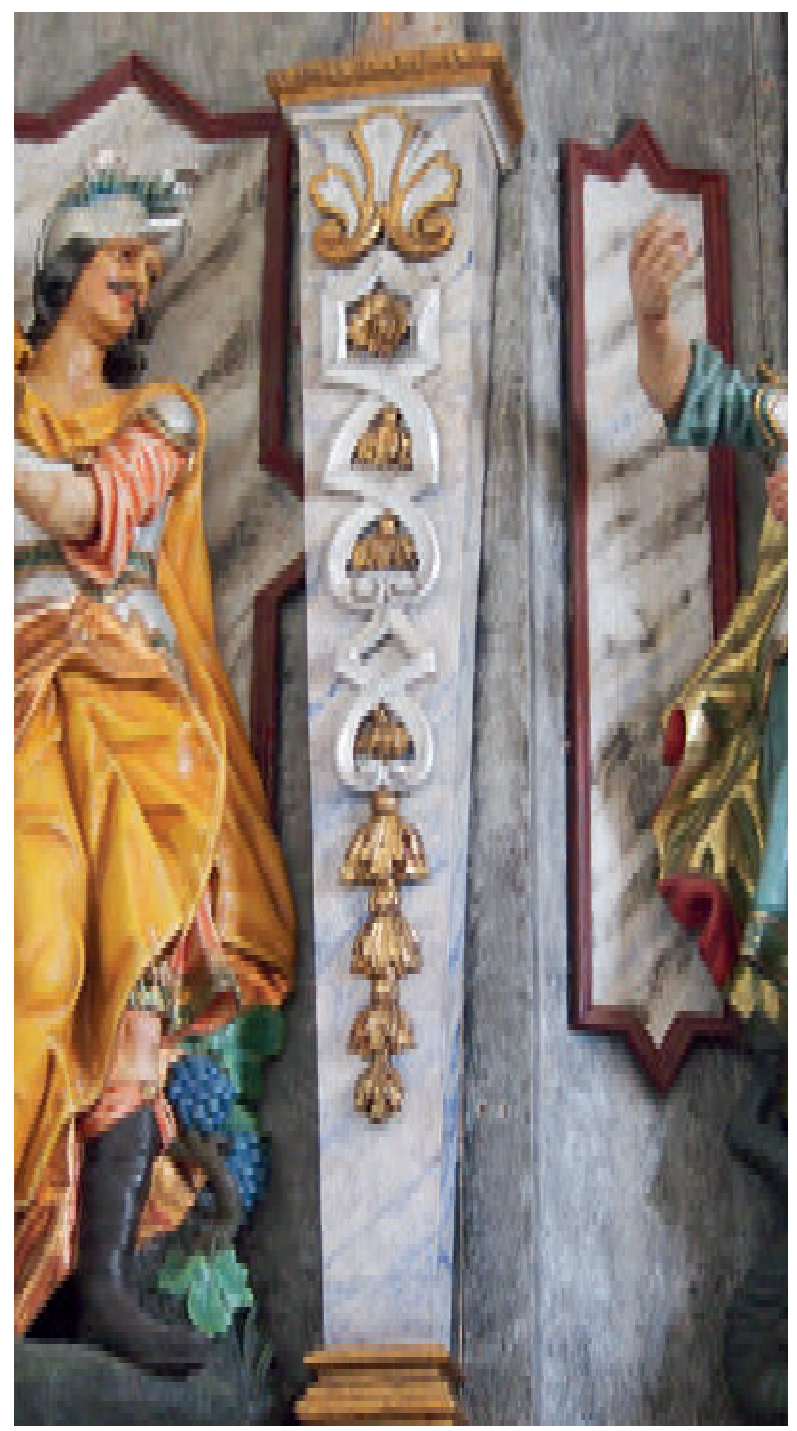

2. Pokupsko, župna crkva sv. Ladislava (Uznesenja Marijina), Glavni oltar - tijelo hermskoga pilastra (snimila: D. Botica). Pokupsko, Parish Church of St. Ladislaus (the Assumption of Mary), main altar - body of a herm pilaster (photo by D. Botica)

njuju iskušana sredstva i rješenja kazališnih scenografija. Jedan od primjera u kojima se uvode takva nova načela oblikovanja scenične kvalitete, a arhitektura glavnoga oltara postaje dio prostornoga oblikovanja građevine, jest i crkva u Pokupskom.

Glavni oltar posve zaklanja začelni zid svetišta te visinom zahvaća u prostor njegova svoda kojem se i prilagođava povijenim oblikom atike (sl. 1). Menza, izdignuta na tri kamene stube supedaneja, nepravilnoga je obrisa, a jak trbušasti naglasak ostvaruje izrazitu konkavno-konveksnu pokrenutost njezina stipesa. Složena arhitektura retabla koji se izdiže nad visokim podnožjem s prolazima ophoda, "gradi“ istaknuto pokrenut prostor. Ona slijedi zakrivljene linije koje određuju i prostor same crkve, meko zaobljenih kutova. Struktura glavnine retabla raščlanjena je šesterim dominantnim nosačima, pri čemu se $u$ dinamičnom ritmu interkolumnija zadanom strukturom podnožja $(a, b, c, b, a)$ naizmjence nižu četiri stupa korintskoga reda i dva hermska pilastra, kod kojih ulogu neposrednih nosača glavnoga gređa preuzimaju naga torza dvaju atlanta. Dojam prostorne dubine potenciraju korintski pilastri uz začelne stranice niša u osi prolazā opohoda. Posebno je zanimljiv prostor $\mathrm{u}$ središnjem dijelu oltara u kojem se nalazi veliki kip titulara - sv. Ladislava. Ne radi se o arhitektonskoj niši, nego o otvorenoj strukturi flankirano boromineskno lomljenim hermskim pilastrima koji središnjim bridovima snažno prodiru u prostor te se tako doimaju gotovo oslobođenima od ostatka oltarne arhitekture (sl. 2). Njihove kerubinske herme nad svetim kraljem pridržavaju baldahin zaključen ukošenim volutama koje, s karakterističnim tekstilnim motivima (lambrekeni) ovješenima duž donjega ruba, podsjećaju na daleki uzor slavnoga Berninijeva Baldacchina (1623.1634.) nad glavnim oltarom u rimskoj bazilici sv. Petra. ${ }^{17}$

Naglašeno pokrenutu tlocrtnu dispoziciju retabla slijedi visoko gređe snažnih obrata, koje istodobno oblikuje prostor i razdvaja strukturne cjeline..$^{18}$ Ono je, scenografski promišljeno, prekinuto u središnjoj osi oltara kako bi se, propuštanjem snopa istočnoga svjetla iz okula apside, dodatno istaknula tu smještena skulptura kraljevskoga titulara. ${ }^{19}$

Osobitost oltara očituje se i u atici, koja visinom gotovo nadmašuje ostatak retabla. Istodobno, prozračnim rasporedom njezinih arhitektonskih i skulpturalnih elemenata postiže se dojam lakoće primjerene svodnoj zoni i usklađene s prisutnim štuko-dekoracijama. Okosnicu atičke strukture čine četiri vitke volute položene na još masivnim postamentima u osi glavnih nosača. One, prkoseći tektonskoj logici, ponovno asocirajući na atičke volute Bernijineva Baldacchina, nose povijeni vijenac na koji se, već duboko u zoni svoda, „spušta“ velika glorija s Presvetim Trojstvom koje kruni Uznesenu Bogorodicu.

Tipološki leksik odmjereno raspoređenih ornamentalnih motiva (glavno dekorativno isticanje, naime, svojom razvedenošću ostvaruju sami članovi oltarne arhitekture) uključuje već uvelike stilizirane listove baroknoga akanta (po dva simetrično suprotstavljena lista s volutnim završecima nad prolazima ophoda; ovalne kartuše aplicirane na konveksne plohe podnožja; velika kartuša s grbom donatora nad središnjom skulpturom; listovi na volutama atike), ali i nove motive, poput stiliziranih plitkih vitica duž friza glavnoga gređa, delikatnih cvjetnih girlandi razasutih između atičkih voluta i završnoga vijenca te na njegovim krajevima postavljenih košarica s cvijećem.

Zasebna su novina, „na pola puta“ između arhitekture i skulpture, i već spominjani hermski pilastri. Njihova izdužena tijela, koja se sužavaju prema bazi, bogato su dekorirana motivima koje nalazimo i u drugim dijelovima crkve: stiliziranim palmetama izvedenim na medaljonima u svodu broda i trakama u prepletu kakve se zatječu na svodu svetišta. 


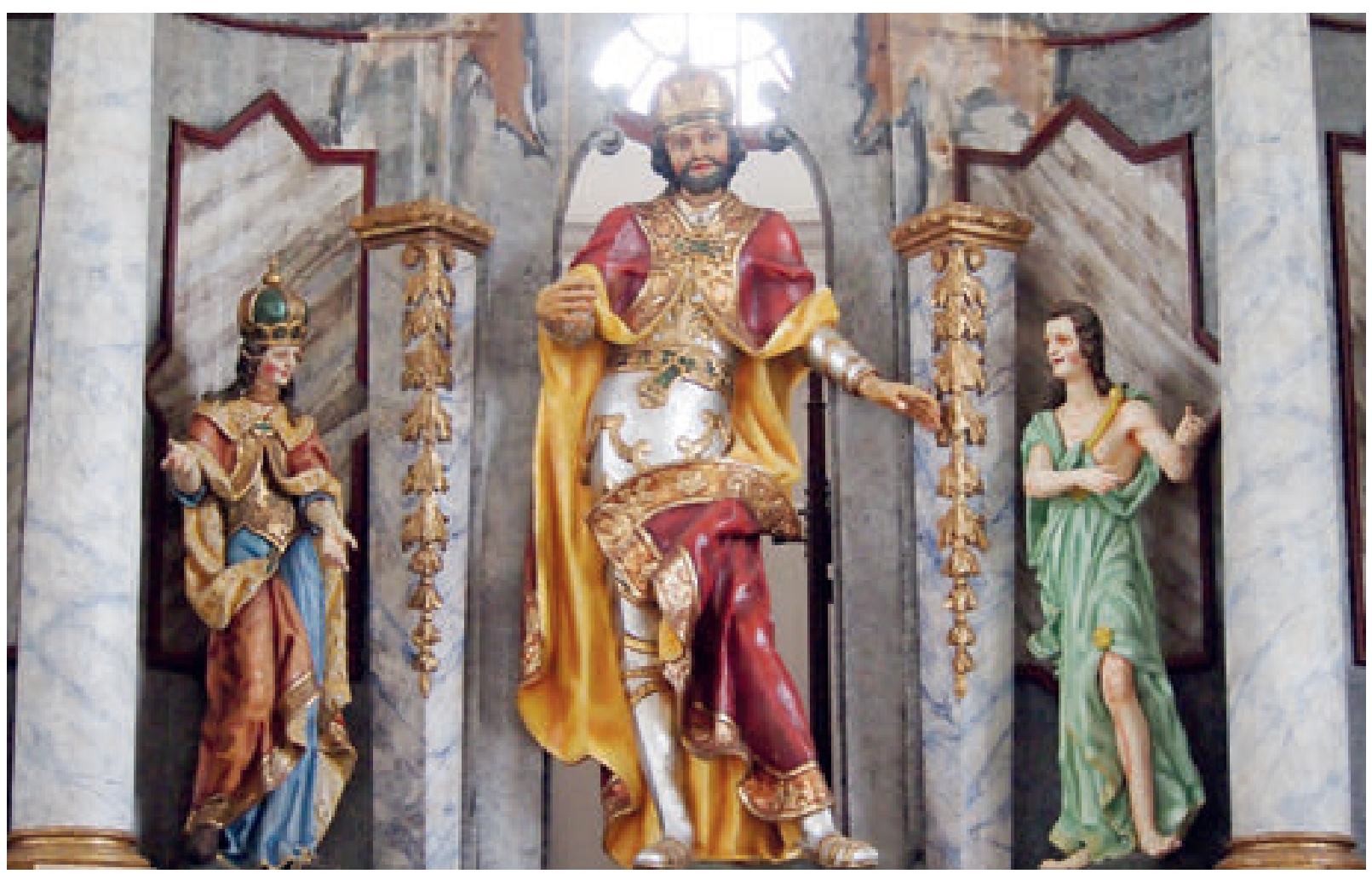

3. Pokupsko, župna crkva sv. Ladislava (Uznesenja Marijina), Glavni oltar - središnja skupina: Sv. Ladislav kralj, kraljica Jelena i anđeo (snimila: D. Botica).

Pokupsko, Parish Church of St. Ladislaus (the Assumption of Mary), main altar - the central group: St. Ladislaus the King, Queen Helena and an angel (photo by D. Botica)

U uvodnom je dijelu, kao jedna od osobitosti crkve sv. Ladislava u Pokupskom, istaknut i specifičan ikonografski program njezina glavnoga oltara. Uz grbove i natpise, njegovi su najvažniji nositelji veliki kipovi razmješteni $\mathrm{u}$ interkolumnijima glavnine retabla. Glavna je skupina ujedno i ključ čitanja programa (sl. 3). ${ }^{\circ} \mathrm{U}$ središtu je smješten kip kralja Ladislava, odjevenoga u raskošni oklop i ogrnutoga pokrenutom draperijom dugoga plašta. U poluuzdignutoj desnici drži prepoznatljiv atribut (bojnu sjekiru), a spuštenom ljevicom pridržava štit s povijesnim ugarskim grbom. Okrunjen je krunom čiji se obrisi gotovo rastaču pod mlazovima svjetla koje kroz okul apside prodire iza njegovih leđa. Kraljeva skulptura dimenzijama nadmašuje sve ostale kipove. Zdesna se kralju obraća lik kraljice Jelene. Spuštenom ljevicom ona upućuje na štit s grbom Trojedne kraljevine (poslije preslikan izmišljenim grbom), ${ }^{21}$ ostvarujući jasnu ikonografsku paralelu s programski najizravnijim prikazom ciklusa s nekadašnjega oltara sv. Ladislava iz zagrebačke katedrale. Nasuprot njoj je lik anđela koji drži štit s kronografskim napisom: »reX sanCte, qVae Vera IMbVIstI fIDe, haeC tVere, et serVa regna« (Sveti kralju, čuvaj i spasi ova kraljevstva koja si poučio pravoj vjeri), poslije preslikanim hrvatskim grbom. Zbroj istaknutih znakova daje 1739., odnosno godinu dovršetka oltara. Sam natpis ističe, u poslijetridentskom razdoblju nedvojbeno bitnu, kraljevu ulogu u širenju prave vjere, aludirajući i na njegov status „apostola Slavonije“, istaknut upravo u naslovu spomenute Vitezovićeve rasprave o Ladislavovu podrijetlu (1704.). Središnju skupinu flankiraju kipovi četiriju rimskih svetaca-vojnika: Donata, Jurja, Martina i Florijana. Neuobičajena ikonografska pratnja svecu obično prikazivanom s također kanoniziranim pripadnicima ugarske kraljevske dinastije (sv. Stjepan, sv. Emerik; iznimno poljski kraljević sv. Kazimir), ponovno upućuje na osobite namjere naručitelja. ${ }^{22} \mathrm{Uz}$ posebnu vezu sa sestrom Jelenom kao nasljednicom hrvatske krune, kralj Ladislav se tu prikazuje kao blizak viteško-herojskom idealu ranokršćanskih svetaca-vojnika, krotkih mučenika, ali i protagonista slavne povijesti.

Osim već spomenute skupine Presvetoga Trojstva i Blažene Djevice Marije, te brojnih putta i dvaju anđela posjednutih na patuljaste odsječke zabata, atiku krase i dvije manje ženske figure, personifikacije teoloških vrlina Nade (Spes) i Ljubavi (Caritas). ${ }^{23}$

\section{Oltari sv. Marije i sv. Josipa - opis}

Važnu ulogu u umjetničkom ansamblu crkve sv. Ladislava u Pokupskom imaju i bočni oltari posvećeni Kristovim zemaljskim roditeljima, smješteni u svođenom slavoluku na ulazu u prostor svetišta. Konstrukcijski pandani, već samim dijagonalnim postavom u odnosu na središnju os kretanja, ti oltari dodatno ističu njegov okvir. Ipak, manjim 


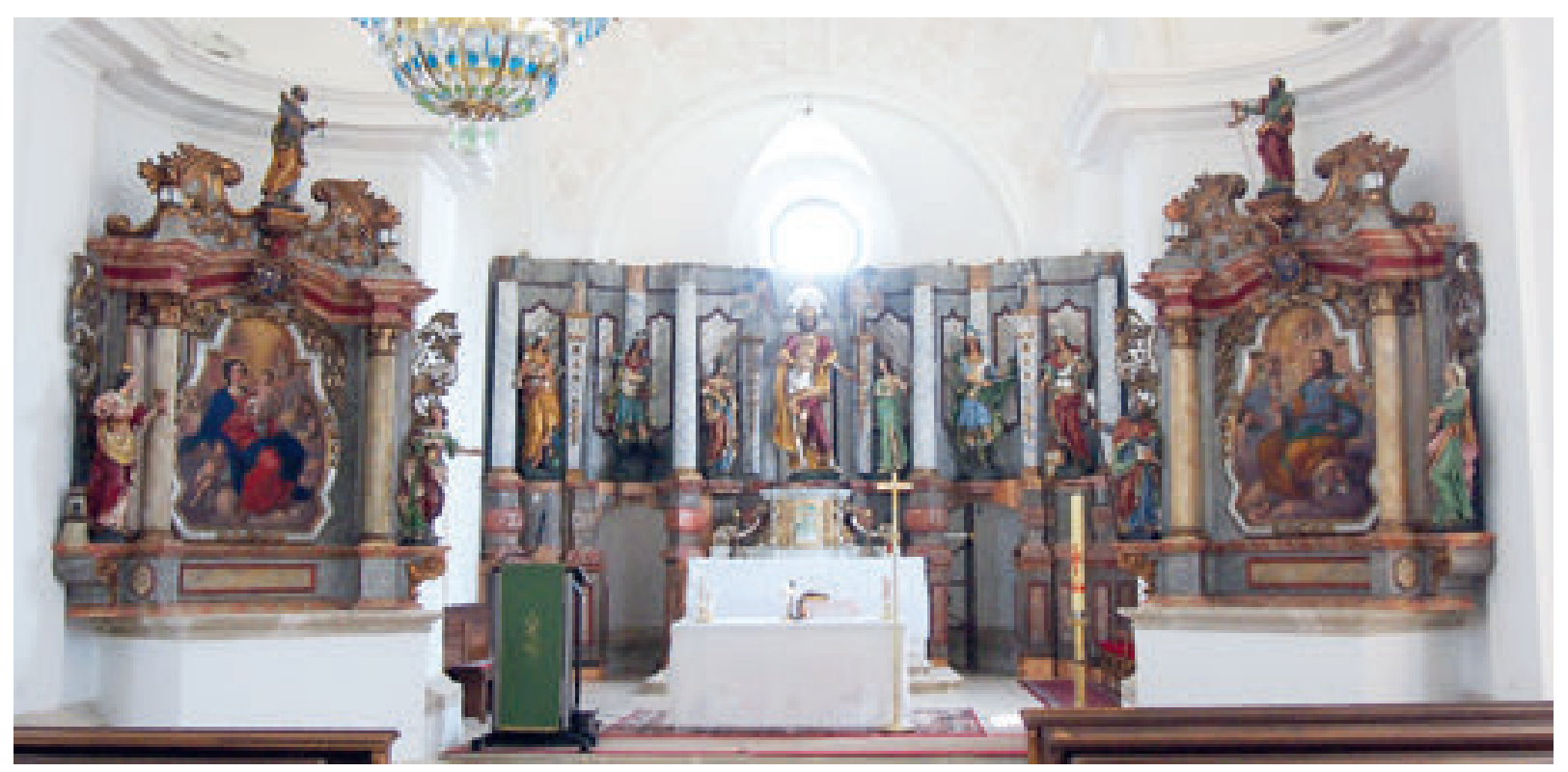

4. Pokupsko, župna crkva sv. Ladislava (Uznesenja Marijina), pogled na glavni oltar i oltare sv. Marije i sv. Josipa (snimila: D. Botica). Pokupsko, Parish Church of St. Ladislaus (the Assumption of Mary), view of the main altar and altars of St. Mary and St. Joseph (photo by D. Botica)

se dimenzijama, u pogledu iz broda ne nameću glavnom oltaru te s njime tvore vizualno proporcionalnu cjelinu. Unutar svođenoga slavoluka ostvaren je tako scenično jedinstveni prostor koji se nastavlja na brod namijenjen vjernicima te omogućuje postupni prijelaz u prostor svetišta kakav će se ustaljeno oblikovati u sakralnim interijerima XVIII. stoljeća (sl. 4).

Oba se oltarna nastavka, postavljena na jednostavne zidane menze izdignute na dvije stube supedaneja, prilagođavaju zakrivljenom zidnom plaštu svođenoga slavoluka (sl. 5). Nad niskom zonom predele izdižu se retabli definirani parovima nosača - kompozitnih stupova postavljenih ispred plitkih pilastara istoga reda - koji nose jednostavno, u središnjem dijelu segmentno potisnuto gređe. U zoni gređa, u središnjoj osi obaju oltara, pričvršćeni su grbovi biskupa Branjuga unutar akantovih kartuša. Parovi nosača, kao i njihovi pravokutni postamenti u zoni predele te istaknuti obrati gređa, dijagonalno su ukošeni prema središnjoj osi retabla, ostvarujući tako promišljenu prostornu protutežu konkavno uvučenoj stijeni svođenoga slavoluka. Cjelinu flankiraju asistentske skulpture (sv. Barbare i svetice bez atributa - vjerojatno sv. Katarine - na oltaru sv. Marije, ${ }^{24}$ te svetih Joakima i Ane na oltaru sv. Josipa) smještene na volutnim konzolama bočno istaknutim $u$ zoni predele. Asistentske skulpture, gotovo posve neovisne o oltarnoj arhitekturi, istaknute su tek prozračnim okvirom „krila“ u dekorativnom prepletu akanta, mreža i voluta (sl. 5). Atike bočnih oltara zaključuju manje skulpture apostolskih prvaka - sv. Petra (na oltaru sv. Marije) i sv. Pavla (na oltaru sv. Josipa). Posebno je zanimljiva pojava novoga oblika okvira oltarne slike: trbušasto povijenih bočnih stranica i lučno potisnute gornje stranice, te zasječenih donjih kutova. Novina takvoga tipa okvira u altarističkoj praksi kontinentalne Hrvatske, te pojava istovrsnoga oblika na prozoru zvonika crkve sv. Ladislava, podsjeća na činjenicu hotimice usklađenoga projekta (Gesamkunstwerk) arhitekture i opreme crkve (sl. 6). Takvo rješenje prozorskih otvora nalazi se u opusu vodećega gradačkoga graditelja toga razdoblja, Johanna Georga Stengga (npr. na pročelju gradačke crkve hospitalaca - Barmherzigenkirche), na djelima iz čije je radionice i srodna crkva u Pokupskom. Stengg usvaja oblike koje desetljeće prije u austrijski barok uvodi J. Lucas von Hildebrandt u suradnji s Antonijem Beduzzijem, koristeći taj oblik okvira i na oltarima (u kapeli u dvorcu Gornji Belvedere, 1721.) i kao okvir otvora (dvorac Eugena Savojskog u Ráckeve, 1701.). Preuzet iz Guarinijevih projekata za crkve sv. Filipa Nerija u Torinu i crkve S. Maria della Divina Provvidenza u Lisabonu (oba iz 1679.), taj nepravilan okvir prozora, kao i drugi oblici okvira te dekoracija iz Guarinijeva opusa, vrlo brzo se preko grafičkih prikaza u traktatima i opisa početkom 18. stoljeća šire srednjom Europom. ${ }^{25}$ Primjer ponavljanja rješenja prozorskoga otvora sa zvonika na okviru slika bočnih oltara crkve u Pokupskom, potvrđuje praksu korištenja zajedničkih predložaka i crteža kako za arhitekturu, tako i za opremu i dekoraciju građevine, koja je bila učestala u srednjoeuropskim graditeljskim radionicama.

Svjesnu težnju k oblikovnoj usklađenosti raznih faza gradnje i opremanja crkve u Pokupskom potvrđuje i već istaknuta prisutnost istih ornamentalnih motiva na glavnom oltaru i štuko-dekoracijama zidnoga plašta (palmete, prepletene trake). Na bočnim oltarima njima se pridružuje i romboidna mreža s rozetama na čvorištima, motiv koji 


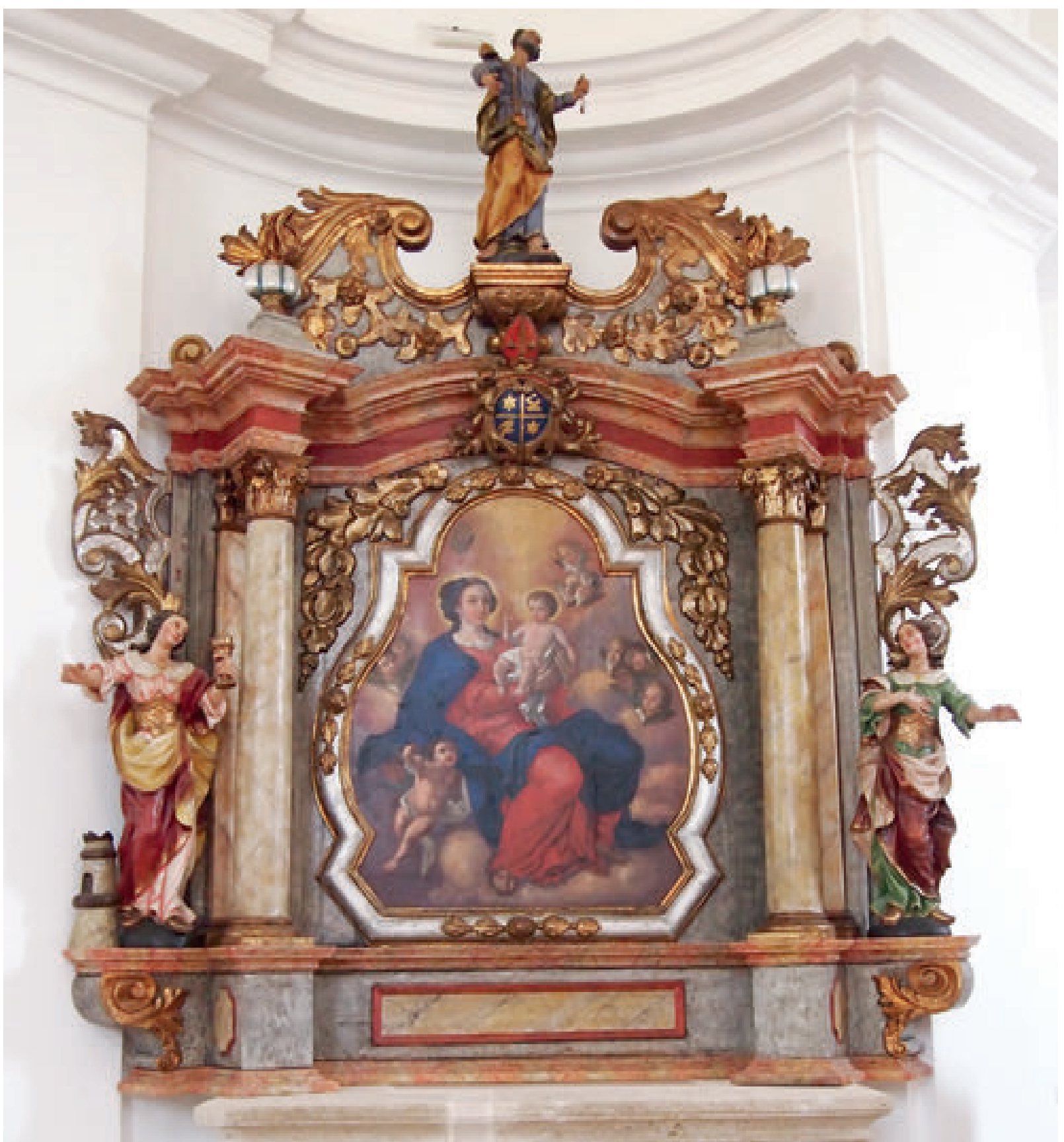

5. Drvorezbarska radionica biskupa Jurja Branjuga, Oltar sv. Marije, 1739., Pokupsko, župna crkva sv. Ladislava (snimila: D. Botica). Woodcarving workshop of Bishop Juraj Branjug, St. Mary's Altar, 1739, Pokupsko, Parish Church of St. Ladislaus (photo by D. Botica)

je, uz prepletene trake (Bandelwerk), dominirao srednjoeuropskim rokokoom (sl. 7). ${ }^{26}$

\section{Oprema crkve sv. Ladislava u Pokupskom u kontekstu barokne altaristike kontinentalne Hrvatske}

Crkvu sv. Ladislava u Pokupskom i njezinu bogatu opremu u stručnu je literaturu u sklopu projekta Popisivanje i fotografijsko snimanje umjetničkih spomenika uveo Artur Schneider (1941.). ${ }^{27}$ O oltarima i propovjedaonici opetovano je pisala Doris Baričević (1975., 1994., 2008.), prepoznavši u njima ključna ostvarenja „drvorezbarske radionice biskupa Jurja Branjuga“. ${ }^{28}$ Potaknuta bilješkom zagrebačkoga kanonika i kroničara Baltazara Adama Krčelića (Šenkovec, 1715. - Zagreb, 1778.) o radionici koja je pod okriljem Jurja Branjuga tijekom prve polovice XVIII. stoljeća na zagrebačkom Kaptolu izrađivala oltare i propovjedaonice koje je biskup darivao crkvama diljem biskupije, autorica je, počevši upravo od opreme crkve u Pokupskom, oformila opus koji uključuje niz srodnih djela u crkvama sjeverozapadne Hrvatske. Tijekom višedesetljetne djelatnosti radionice (koja se uglavnom poklapa s razdobljem Branjugova biskupovanja), u njoj se izmijenilo nekoliko vodećih kiparskih osobnosti. Iako altaristički aspekt radionice odražava homogeniji karakter, 


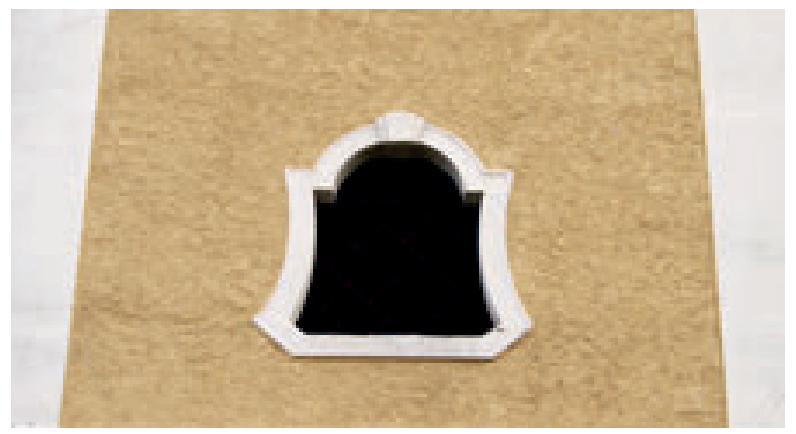

6. Pokupsko, crkva sv. Ladislava (Uznesenja Marijina), prozor zvonika (snimila D. Botica).

Pokupsko, Parish Church of St. Ladislaus (the Assumption of Mary), window of the bell tower (photo by D. Botica)

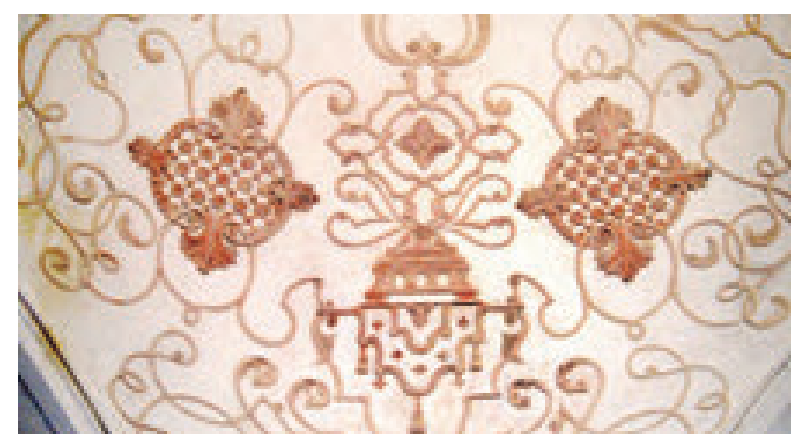

7. Pokupsko, crkva sv. Ladislava (Uznesenja Marijina), štukature na svodu svetišta (snimila D. Botica).

Pokupsko, Parish Church of St. Ladislaus (the Assumption of Mary), stucco decorations on the vault of the sanctuary (photo by D. Botica)

i tu - primjerice u slučaju pokupskih oltara - susrećemo novine koje će se poslije pojavljivati u djelima same radionice, ali i u opusima njezinih suvremenika, odnosno umjetnika koji su sljedećih desetljeća dominirali zagrebačkom kiparskom scenom.

Pokrenutim tlocrtnim rasporedom i složenom arhitektonskom kompozicijom te inovativnim dekorativnim motivima, glavni oltar župne crkve u Pokupskom ostvaruje važnu ulogu u prostornom oblikovanju svetišta, preuzimajući vizualnu funkciju njegova zaključnog zida. ${ }^{29}$ Jedan od prvih tako koncipiranih oltara u austrijskim zemljama - iz kojih su se utjecaji širili i na prostor sjeverozapadne Hrvatske - bio je glavni oltar augustinskoga samostana u štajerskom Vorauu (1701./1704.), projekt bečkoga dvorskoga arhitekta Matthiasa Steinla. ${ }^{30}$ Ključna uloga pozadinskoga osvjetljenja $u$ funkciji isticanja dramatike skulpturalnih prizora proizlazila je pri tome iz utjecajnih rimskih ostvarenja kipara i arhitekta Giana Lorenza Berninija, osobito oltara sv. Terezije Avilske u kapeli Cornaro (1647-1652.) u crkvi Santa Maria della Vittoria. ${ }^{1}$ Srodnosti s pokupskim oltarom prepoznajemo, iako u mnogo monumentalnijem oblikovanju i dimenzijama, i u rješenju glavnog oltara (1727.-1734.) u samostanskoj crkvi u Melku, djelu Antonija Beduzzija

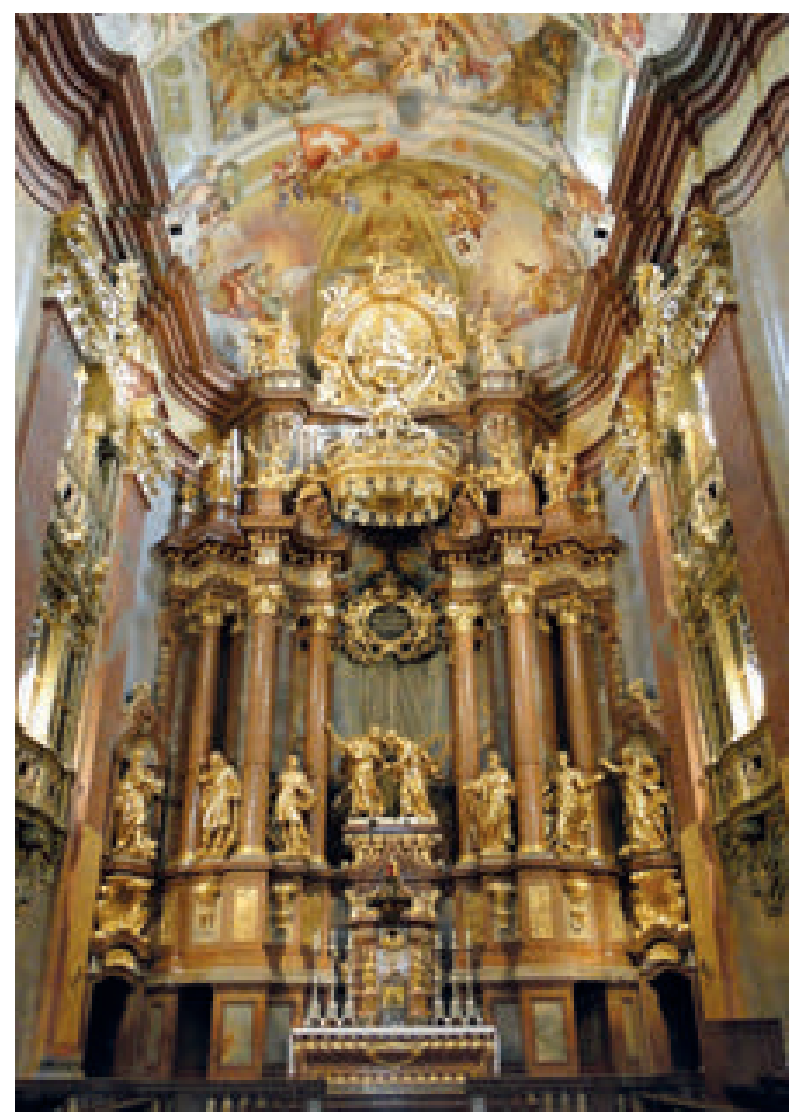

8. Antonio Beduzzi, Glavni oltar, 1727.-1734., Melk, benediktinska crkva svetih Petra i Pavla.

Antonio Beduzzi, main altar, 1727-1734, Melk, the Benedictine Church of Sts. Peter and Paul

(sl. 8). Na njemu je, kao i na našem primjeru, arhitektura „potisnuta“ od središta u kojem se događa narativan skulptorski prizor, ${ }^{32}$ a gređe je u središtu prekinuto. Kao i u Pokupskom, središnji je dio nadvišen baldahinom s volutama i lambrekenima.33

Kao ranu pojavu takvoga promišljanja oltarne arhitekture - koja se oblikom prilagođava obliku apside te „osvaja“ svetišni prostor dinamičnim ritmom interkolumnija i snažnim obratima gređa - na prostoru sjeverozapadne Hrvatske moguće je navesti glavni oltar hodočasničke crkve Majke Božje Snježne u Volavju, datiran u sredinu prvoga desetljeća XVIII. stoljeća. ${ }^{34}$ Primjer daljnjega razvitka toga tipa, u sklopu razgranate produkcije drvorezbarske radionice biskupa Jurja Branjuga, jest - prostorno razvijeniji - glavni oltar kapele Sveta tri kralja u Kominu, podignut 1729. godine (sl. 9). ${ }^{35} \mathrm{~Pa}$ ipak, kod kominskoga, kao i kod oltara iz crkve u Volavju, još uvijek se susrećemo s elevacijom tipičnom za prijašnja razdoblja, u kojoj masivna atika, rasporedom jasno definiranih arhitektonskih članova, u reduciranom opsegu i umanjenom mjerilu ponavlja rješenje glavnine retabla. Osobitost glavnoga oltara u Pokupskom transparentna je pak struktura visoke atike čiju okosnicu tvore vitke, uspravljene volute koje gotovo atektonskom lakoćom podupiru zaključni 


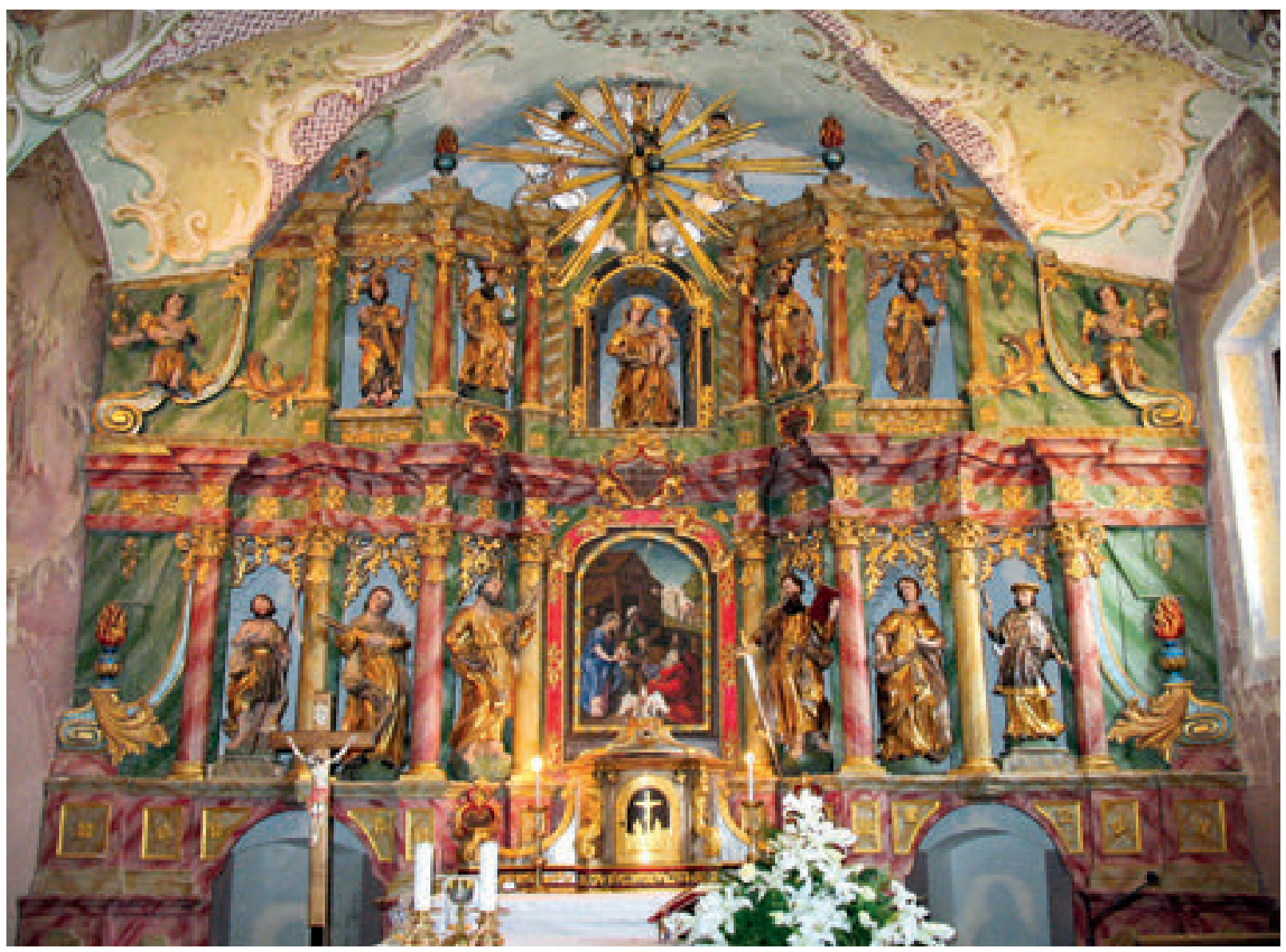

9. Drvorezbarska radionica biskupa Jurja Branjuga, Glavni oltar, 1729., Komin, hodočasnička crkva Sveta tri kralja (snimio D. Šourek.). Woodcarving workshop of Bishop Juraj Branjug, main altar, 1729, Komin, the Pilgrimage Church of the Three Magi (photo by D. Šourek)

vijenac. Prozračnom dojmu cjeline pridonose i ornamentalni elementi (osobito nježne cvjetne girlande razapete između voluta i vijenca) te skulpture koje kao da lebde pred tim lakim okvirom. Rani primjer takvoga tretmana atike zatječe se na glavnom oltaru župne crkve sv. Marije Magdalene u Čazmi (1725.), djelu nepoznatoga majstora djelatnoga tijekom trećega i četvrtoga desetljeća XVIII. stoljeća..$^{36} \mathrm{U}$ tipičnom rješenju atike, ali i zamisli cijeloga retabla, pokupskom oltaru najbližim se pak čini glavni oltar župne crkve Majke Božje Snježne u Kutini (1746.), rad Josipa Weinachta, kipara koji je djelovao na zagrebačkom Kaptolu upravo u vrijeme kad su ondje boravili $i$ anonimni članovi Branjugove drvorezbarske radionice (sl. 10). ${ }^{37}$ Iako u kiparskoj vještini Weinacht nadilazi ostvarenja „Branjugovih“ kipara, srodnost altarističkih rješenja pokupskoga i kutinskoga oltara navodi na pomisao o mogućoj suradnji dviju radionica. Uz istaknutu razvedenost tlocrta i uspravljene atičke volute povezane cvjetnim girlandama, poveznica dvaju glavnih oltara je i promišljena, scenografska uloga svjetla koje dopire iz začelnoga okula: dok se u Pokupskom u funkciji njegova usmjeravanja na središnju skulpturu prekida pojas glavnoga gređa, na kutinskom oltaru s istim je ciljem sugestivnoga osvjetljenja skupine Presvetoga Trojstva, prekinuto zaključno gređe atike. Naposljetku, i Weinachtova uočena sklonost »da u središte svojih oltara umjesto slike u nišu postavi kip i motiv obogati raznim elementima inscenacije«, zamjetna primjerice na glavnom oltaru župne crkve sv. Martina u Velikoj Trnovitici (1746.) ili središnjoj skupini Smrti sv. Marije Magdalene naknadno (oko 1750.) umetnute u nišu glavnog oltara župne crkve u Čazmi, ${ }^{38}$ pronalazi paralelu $\mathrm{u}$ „redateljskom“ smještaju središnjih kipova pokupskoga oltara koji se, poput glumaca s pozornice, rječitim gestama obraćaju promatraču.

Poveznice s rješenjima Branjugove drvorezbarske radionice - posebice s arhitekturom i ornamentikom glavnoga oltara u Pokupskom - moguće je uočiti i u opusima dvojice kipara koji su u nešto kasnijem razdoblju djelovali na zagrebačkom Gradecu. Riječ je o Antunu Reineru i njegovu vjerojatnom suradniku Antunu Franji Risneru. ${ }^{39}$ Tako i na Rienerovu glavnom oltaru župne crkve svetih Petra i Pavla u Petrovskom nedaleko od Krapine (1756.), uz opću arhitektonsku koncepciju srodnu oltaru iz Pokupskoga, u središtu zatječemo scenografski oživljenu skupinu Predaje ključeva, u kojoj se Kristu i sv. Petru poput promatrača pridružuju još i Bogorodičini roditelji Joakim i Ana. Paralele pronalazimo i u bogatom dekorativnom repertoaru dvojice majstora, poput karakterističnih prepleta mreža 


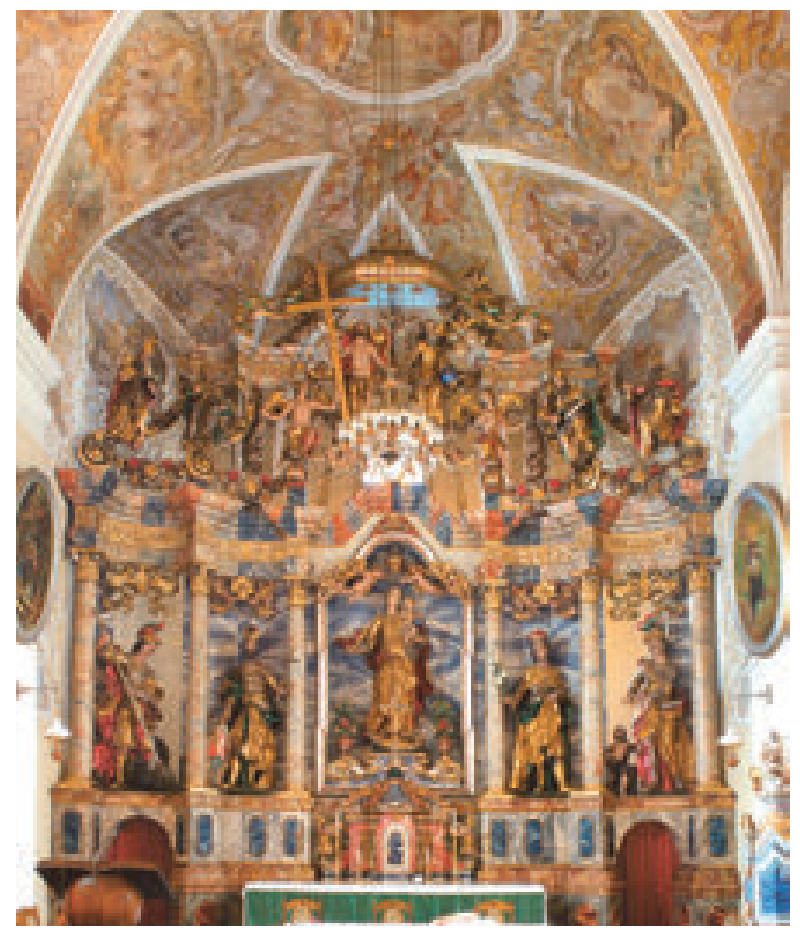

10. Josip Weinacht, Glavni oltar, 1746., Kutina, župna crkva Majke Božje Snježne. Izvor: D. BARIČEVIĆ, Barokno kiparstvo sjeverne Hrvatske, Zagreb, 2008., 112.

Josip Weinacht, main altar, 1746, Kutina, the Parish Church of St. Mary of the Snow. Source: D. BARIČEVIĆ, The Baroque Sculpture of Northern Croatia, Zagreb, 2008, pp. 112

s rozetama, akanta i voluta (npr. na Reinerovu glavnom oltaru kapele svetih Petra i Pavla u Boku (sl. 11) iz 1750. godine) ili hermskih pilastara s nagim torzima posve srodnim onima na glavnom oltaru u Pokupskom (na Risnerovu oltaru sv. Josipa iz sedmoga desetljeća XVIII. stoljeća, u župnoj crkvi sv. Ane u Osekovu).4

\section{Zaključak}

Oltarni ansambl, a osobito glavni oltar župne crkve u Pokupskom, ikonografskim programom i umjetničkom kvalitetom zamisli odražava visoke naručiteljske kriterije

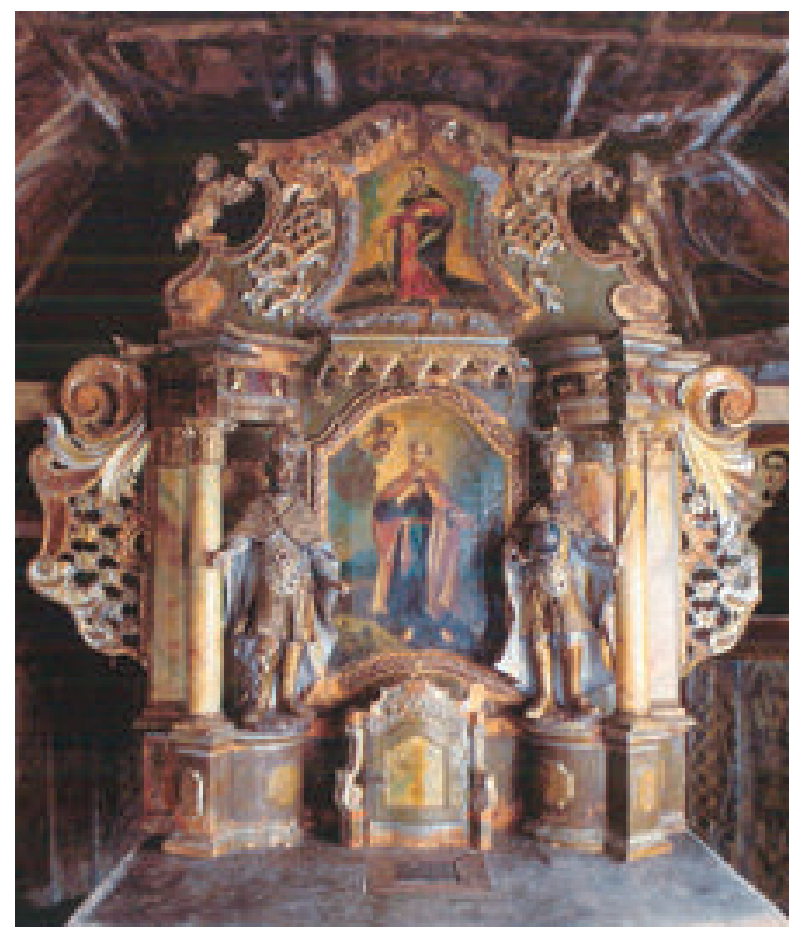

11. Antun Reiner, Glavni oltar, oko 1750., Bok, kapela svetih Petra i Pavla. Izvor: D. BARIČEVIĆ, Barokno kiparstvo sjeverne Hrvatske, Zagreb, 2008., str. 131.

Antun Reiner, main altar, around 1750, Bok, the Chapel of Sts. Peter and Paul. Source: D. BARIČEVIĆ, The Baroque Sculpture of Northern Croatia, Zagreb, 2008, pp. 131

zagrebačkoga biskupa Jurja Branjuga. Moguće je pretpostaviti i da je biskupova drvorezbarska radionica, koja je već poznavala srednjoeuropska altaristička rješenja, tu naišla na nove utjecaje štajerskih majstora zaslužnih za projekt same crkve. Neka se od arhitektonskih i dekorativnih rješenja primijenjenih na pokupskim oltarima ne opetuju samo u sklopu opusa iste radionice, već svoju inovativnu kvalitetu i važnost u korpusu barokne altaristike sjeverozapadne Hrvatske potvrđuju širim utjecajem na, prije svega zagrebačko, kiparstvo, tj. altaristiku XVIII. stoljeća.

\section{Bilješke}

1 Opširnije o značenju crkve sv. Ladislava u korpusu arhitekture 18. stoljeća usp. DUBRAVKA BOTICA, Četverolisne crkve u srednjoj Europi - problem tipologije sakralne arhitekture 18. stoljeća, doktorska disertacija, Filozofski fakultet Sveučilišta u Zagrebu, Zagreb, 2007.

2 Njemački izraz Gesamtkunstwerk moguće je prevesti kao zbirno ili potpuno umjetničko djelo, nastalo kao plod jedinstvenoga naručiteljskoga, odnosno umjetničkoga promišljanja.
3 Usp. DORIS BARIČEVIĆ, Majstori drvorezbarske radionice biskupa Jurja Branjuga u Pokupskom, u: Kaj. Časopis za kulturu i prosvjetu VII, 5-6, Zagreb, 1974., 178-180; DORIS BARIČEVIĆ, Barokno kiparstvo sjeverne Hrvatske, Zagreb, 2008., 102-110.

4 Usp. MATIJA JURAKOVIĆ, Obnova i rušenje crkve u Pokupskom, u: Pokupsko 1991.-1996. Monografija, (ur.) Aleksandar Božić, Općina Pokupsko - Glasnik Turopolja, Velika Gorica, 1996., 25-27; ALEKSANDAR BOŽIĆ, 
Spašeno kulturno blago iz pokupske crkve, u: Pokupsko 1991.-1996. Monografija, (ur.) Aleksandar Božić, Općina Pokupsko - Glasnik Turopolja, Velika Gorica, 1996., 35; BARICA SAKOMAN, Obnova Crkve i restauriranje župnih umjetnina, u: Pokupsko 1991.-199G. Monografija, Aleksandar Božić (ur.), Općina Pokupsko - Glasnik Turopolja, Velika Gorica, 1996., 42-43; ĐURĐICA CVITANOVIĆ, Crkveni spomenici na području Pokupskog. Ratna razaranja i obnova, u: Pokupsko. Kroz prošlost i sadašnjost, (ur.) Agneza Szabo, Matica hrvatska, Ogranak Pokupsko, Zagreb, 2006., 167171; ALEKSANDAR BOŽıĆ, Spašavanje kulturnog blaga iz pokupske crkve, u: Pokupsko. Kroz prošlost i sadašnjost, (ur.) Agneza Szabo, Matica hrvatska, Ogranak Pokupsko, Zagreb, 2006., 344-352.

5 Osim glavnoga oltara, oltara posvećenih sv. Mariji i sv. Josipu, te propovjedaonice - obilježenih Branjugovim grbovima - istoj se radionici pripisuje i skupina Raspeća s oltara Sv. Križa. Uz njega, u crkvenom brodu nalazio se i nešto mlađi oltar sv. Izidora. Usp. DORIS BARIČEVIĆ, 1974., (bilj. 3), 178-180.

6 Slike s nekadašnjega oltara sv. Ladislava iz sjeverne apside, kao i one s oltara sv. Marije, koji se do potresa 1880. godine nalazio u južnoj apsidi zagrebačke katedrale, ljubljanskom slikaru Ivanu Eisenhartu (loannes Eisenhordt) pripisala je Sanja Cvetnić (2000.) Usp. SANJA CVETNIĆ, Djela ljubljanskoga slikara loannesa Eisenhordta u Zagrebu, u: Acta historiae artis Slovenica 5, Ljubljana, 2000., 83-108. Usp. također: SANJA CVETNIĆ, Slikarstvo u kontinentalnoj Hrvatskoj, u: Hrvatska i Europa. Kultura, znanost i umjetnost, sv. III., Barok i prosvjetiteljstvo (XVII.-XVIII. stoljeće), (ur.) Ivan Golub, Školska knjiga, Zagreb, 2003., 653-662 (654-655). Od ukupno dvanaest slika višekrilnog oltara, sačuvano ih je deset. U Muzeju grada Zagreba nalaze se slike: Kralj Ladislav u borbi s Kumanima, Molitva kralja Ladislava, Kralj Ladislav moli prije bitke, Kralj Ladislav zaštićuje udovice i siročad, Kralj Ladislav dariva biskupa Duha, Biskup Duh predaje Ladislavu krunu, Graditelj pokazuje Ladislavu nacrt katedrale, Kralj Ladislav promatra gradnju katedrale i Hrvatski velikaši pred kraljem Ladislavom. Slika Kralj Ladislav dijeli milostinju nalazi se u Muzeju za umjetnost i obrt. O ikonografskom programu ciklusa vidi: ANĐELA HORVAT, Barok u kontinentalnoj Hrvatskoj, u: Barok u Hrvatskoj, (ur.) Anđela Horvat, Radmila Matejčić i Kruno Prijatelj, Sveučilišna naklada Liber, Zagreb, 1982., 3-381 (161). Vidi također: DANKO ŠOUREK, »Ad imitationem angelicae, apostolicaeque coronae Vngariae«. Prilog ikonografiji krune na prikazima svetih kraljeva u zagrebačkoj katedrali, u: Peristil. Zbornik radova za povijest umjetnosti 54, Zagreb, 2011., 177-186; DUBRAVKA BOTICA Iconography of the Holy King Ladislaus in Zagreb Diocese in Late $17^{\text {th }}$ and Early $18^{\text {th }}$ Century. New Reading of the Past in Central European Context, u: IKON - Journal of Iconographic Studies 5, Rijeka, 2012., 263-272.

7 Poveznicu ciklusa slika s nekadašnjega oltara sv. Ladislava i ikonografskoga programa glavnoga oltara župne crkve u Pokupskom prepoznaje već Anđela Horvat koja, osvrćući se na njezinu opremu (1982.), ističe: »Ono što je kulturnohistorijski zanimljivo, to je opet politička ideja ujedinjenja hrvatskih zemalja povezana Ladislavom kao i na njegovu oltaru zagrebačke katedrale iz vremena oko 1700.«ANĐELA HORVAT, 1982., (bilj. 6), 223.

8 U posjedu zagrebačkoga biskupa imanje se navodi i u popisu urbarskih zemljišta u Hrvatskoj i Slavoniji iz 1848. godine. Usp. JOSIP HORVAT, Kultura Hrvata kroz 1000 godina II., Globus, Zagreb, 1980. [I. izdanje: 1939.], 420. 9 Usp. ANDRIJA LUKINOVIĆ, Zagreb - devetstoljetna biskupija, Glas koncila, Zagreb, 1995., 241.

10 Usp. DUBRAVKA BOTICA, Zagrebački biskup Juraj Branjug - naručitelj gradnje župne crkve Sv. Ladislava u Pokupskom. Uloga naručitelja u odabiru arhitektonskog tipa, u: Umjetnost i naručitelji, Zbornik radova znanstvenog skupa »Dani Cvita Fiskovića održanog 2008. godine, (ur.) Jasenka Gudelj, Odsjek za povijest umjetnosti Filozofskog fakulteta Sveučilišta u Zagrebu, Institut za povijest umjetnosti, Zagreb, 2010., 125-136.

11 O biskupu Jurju Branjugu vidi: ANTE SEKULIĆ, Juraj Branjug 1723.-1748., u: Zagrebački biskupi i nadbiskupi, (ur.) Juraj Batelja, Školska knjiga, Zagreb, 1995., 393-396; ANDRIJA LUKINOVIĆ, 1995., (bilj. 9), 237-242.

12 Usp. SANJA CVETNIĆ, Ikonografija nakon Tridentskoga sabora i hrvatska likovna baština, FF press, Zagreb, 2007., 42- 48; DUBRAVKA BOTICA, 2012., (bilj. 6)

13 Usp. ANĐELA HORVAT, 1982., (bilj. 6), 161.

14 Usp. RÓZSI WOLF, Giacchino Pizzoli, affrescatore del Collegio Ungaro-Illirico di Bologna, Franklin, Budapest, 1929.; DUBRAVKA BOTICA, 2012., (bilj. 6); DANIEL PREMERL - IVA KURELAC, Sveti Ivan pustinjak u hrvatskoj historiografiji i ikonografiji 17. i 18. stoljeća, u: Croatica Christiana periodica XXXVI/69, 2012., 23-25. O Bolonjskome kolegiju vidi: GIAN PAOLO BRIZZI - MARIA LUISA ACCORSI - DAMIR BARBARIĆ - PÉTER SÁRKÖZY, Annali del Collegio Ungaro-Illirico di Bologna 1553--1764., Comune di Bologna - Università degli Studi di Bologna, Bologna, 1988. 15 O burgu i vlastelinstvu Steničnjak koje je neposredno graničilo s vlastelinstvom Pokupsko vidi: FILIP ŠKILJAN, Srednjovjekovni grad Steničnjak na Kordunu, u: Radovi Zavoda za hrvatsku povijest XXXVIII/1, Zagreb, 2006., 93112 (i ondje navedena prijašnja literatura).

16 Javljaju se dekorativni motivi karakteristični za srednjoeuropsku inačicu rokokoa: mreže s rozetama na čvorištima, trake u prepletu, odn. Bandlwerk, lambrekeni, palmete; a kompozicijsko rješenje ukazuje na utjecaj francuskih predložaka. Opširnije usp. DUBRAVKA BOTICA, Štukature u župnoj crkvi sv. Ladislava u Pokupskom. Prilog korpusu štukature 18. stoljeća u kontinentalnoj Hrvatskoj, u: Sic ars depreditur arte. Zbornik u čast Vladimira Markovića, (ur.) Sanja Cvetnić, Milan Pelc i Daniel Premerl, Institut za povijest umjetnosti, Odsjek za povijest umjetnosti Filozofskog fakulteta Sveučilišta u Zagrebu, Zagreb, 2009., 67-80. 
17 Usp. RUDOLF WITTKOWER, Bernini. The Sculptor of the Roman Baroque, Phaidon Press, New York, 2009. [I. izdanje 1955.], 244-245.

18 Oltar je obnovljen i postavljen u crkvu do visine gređa (stanje u lipnju 2014.). Gređe i atika analizirani su prema snimci iz Schneiderova fotografskog arhiva HAZU-a iz 1939. godine.

19 Usp. također DORIS BARIČEVIĆ, 1974., (bilj. 3), 178. 20 Već Doris Baričević (1974.) iznosi pretpostavku kako je zamisao središnjega prizora oltara potekla od samoga naručitelja. Usp. DORIS BARIČEVIĆ, 1974., (bilj. 3), 180. 21 Opširan opis izvornoga izgleda oltara u sklopu protokola kanonske vizitacije provedene već u godini posvete crkve (1740.) donosi zagrebački kanonik Stanislav Pepelko (Nadbiskupijski arhiv u Zagrebu, Protokoli kanonskih vizitacija arhiđakonata Katedrala, knj. 55/XI.). Usp. DORIS BARIČEVIĆ, 1974., (bilj. 3), 178.

22 O neobičnosti ikonografskoga odabira svjedoči i činjenica da je u prvom povijesno-umjetničkom osvrtu na oltar (1941.) figura anđela desno od kralja bila pogrešno prepoznata upravo kao sv. Emerik. Usp. ARTUR SCHNEIDER, Popisivanje i fotografijsko snimanje umjetničkih spomenika 1939. godine, u: Ljetopis Jugoslavenske akademije znanosti i umjetnosti za godinu 1939./1940., Zagreb, 1941., 171-186 (182). O ikonografiji sv. Ladislava vidi: MARIJA MIRKOVIĆ, Ikonografija sv. Ladislava na području Zagrebačke (nad) biskupije, u: Zagrebačka biskupija i Zagreb 1094--1994., (ur.) Antun Škvorčević, Katolički bogoslovni fakultet Sveučilišta u Zagrebu, Zagreb, 1995., 579-591 (o glavnom oltaru u Pokupskom na str. 584).

23 Usp. DORIS BARIČEVIĆ, 1974., (bilj. 3), 180. Na fotografiji iz Schneiderova fotografskog arhiva HAZU-a, desna skulptura u desnici nosi goruće srce (ikonografski atribut personifikacije Ljubavi), no izostaje atribut kod skulpture na lijevoj strani.

24 Usp. DORIS BARIČEVIĆ, 1974., (bilj. 3), 180.

25 Guarinijev traktat Disegni di Architettura civile ed ecclesiastica objavio je B. Vittone 1737. Taj oblik okvira u srednjoeuropskoj umjetnosti širi se i traktatom Paula Deckera, Fürstlicher Baumeister / Oder ArchitecturaCivilis, Wie Grosser Fürsten und Herren Palläste / mit ihren Höfen / Grotten / Orangerien / und anderen dazu gehörigen Gebäuden füglich anzulegen und nach heutiger Art auszuzieren... Augsburg, 1711. drugi dio 1716.

26 DUBRAVKA BOTICA, Decoration in religious architecture of the eighteenth century in the south eastern part of Central Europe, u: Investigating and Writing architectural history: subjects, methodologies and frontiers. Papers from the third eahn International Meeting, (ur.) Michalea Rosso, Politecnico di Torino, Italija, 2014., 163-173. (URL = http://www.eahn2014. polito.it/EAHN2014proceedings.pdf)

27 Usp. ARTUR SCHNEIDER, 1941., (bilj. 22), 182.

28 Usp. DORIS BARIČEVIĆ, 1974., (bilj. 3); DORIS BARIČEVIĆ, Kiparstvo manirizma i baroka, u: Sveti trag. Devetsto godina umjetnosti Zagrebačke nadbiskupije 1094.-1994., (ur.) Tugomir Lukšić, Muzejsko-galerijski centar - Institut za povijest umjetnosti - Zagrebačka nadbiskupija, Zagreb, 1994.a, 202-340 (311); DORIS BARIČEVIĆ, 2008., (bilj. 3) 29 Tu funkciju oltara tipa „apsidaler Kolonnadenaltar“ ističe B. Euler Rolle, „deren Wesen in der Identifikation von architektonischen Chorschlüssen und Altaraufbauten besteht", cit. prema INGEBORG SCHEMPER SPARHOLZ, Barockaltäre in Österreich - Möbel, Schaubühne, Denkmal. Versuch einer typologischen Ordnung, u: Triumph der Phantasie. Barocke Modelle von Hildebrandt bis Molinarrolo, (ur.) Michael Krapf, Böhlau, Beč, 1998., 49-64, (51, 60). 30 INGEBORG SCHEMPER SPARHOLZ, 1998., (bilj. 29), 48, 51.

31 Usp. BRUCE BOUCHER, Italian Baroque Sculpture, Thames and Hudson, London, 1998., 134-142.

32 Formiranje središnje grupe smještene u arhitektonskom sklopu, poput baldahina ili paviljona, karakteristično je za tzv. oprostorene oltare (njem. Altarraum). Rješenje prilagođeno formatu oltara ostvaruje već Giuseppe Pozzo, mlađi brat slikara i arhitekta Andree Pozza, na oltaru u Capella delle Vergine u karmelićanskoj crkvi u Veneciji, 1700. godine. Ono će se, kao i varijacija Andree Pozza iz isusovačke crkve u Beču, preko grafičkih predložaka raširiti cijelom srednjom Europom. Opširnije usp. HERBERT KARNER, Giuseppe Pozzo und der mitteleuropäische Altarbau, u: Barock in Mitteleuropa. Werke, Phänomene, Analysen, Wiener Jahrbuch für Kunstgeschichte, (Festschrift für H. Lorenz) 55/56, Böhlau, Beč, 2006./2007., 225-236. 33 Usp. crteže projekata za oltare iz kataloga radionice Galli-Bibiena u WILHELM GEORG RIZZI, Das Werkskizzenbuch der Familie Galli Bibiena Zwei Entwurfszeichnungen für den Hochaltar, 1725 Zwei Entwurfszeichnungen für Seitenaltäre, vor 1723, u: Triumph der Phantasie. Barocke Modelle von Hildebrandt bis Molilinarrolo, (ur.) Michael Krapf, Böhlau, Beč, 1998., 127-138, 147-150, 155-157.

34 O volavskom oltaru vidi: DORIS BARIČEVIĆ, Drvorezbarstvo i skulptura 17. i 18. stoljeća na području općine Jastrebarsko, u: Kaj - Skriveno blago. Iz riznice umjetničkih znamenitosti jastrebarskoga kraja, Kajkavsko spravišče, Zagreb, 1975., 29-52 (38); DORIS BARIČEVIĆ, 2008., (bilj. 3), 153.

35 O glavnom oltaru kapele u Kominu vidi: DORIS BARIČEVIĆ, 2008., (bilj. 3), 105.

36 O glavnom oltaru župne crkve u Čazmi vidi DORIS BARIČEVIĆ, Majstor glavnog oltara u Čazmi - prilog pokrajinskom kiparstvu sjeverozapadne Hrvatske, u: Vijesti muzealaca i konzervatora Hrvatske XXVIII./4, Zagreb, 1979., 5-12; DORIS BARIČEVIĆ, 2008., (bilj. 3), 181-182, 117 (središnji prikaz smrti sv. Marije Magdalene kasniji je rad zagrebačkoga kipara Josipa Weinachta).

37 O Josipu Weinachtu vidi DORIS BARIČEVIĆ, Josephus Weinacht, sculptor Zagrabiensis, u: Rad Jugoslavenske akademije znanosti i umjetnosti 381, JAZU, Zagreb, 1978., 73-94; 
DORIS BARIČEVIĆ, 2008., (bilj. 3), 113-122 (o kutinskom oltaru na str. 114).

38 Usp DORIS BARIČEVIĆ, 2008., (bilj. 3), 114, 117.

39 O Antunu Reineru i Antunu Franji Risneru vidi: DORIS BARIČEVIĆ, Prijedlog za opus zagrebačkog kipara Antuna Reinera, u: Iz starog i novog Zagreba VI., Muzej grada Zagreba, Zagreb, 1984., 105-120; DORIS BARIČEVIĆ, Barokna skulptura na Gradecu, u: Zagrebački Gradec 1242.-1850., (ur.)
Ivan Kampuš, Lujo Margetić i Franjo Šanjek, Grad Zagreb, Zagreb, 1994.b, 343-368 (352-353, 360); DORIS BARIČEVIĆ, 2008., (bilj. 3), 130-134, 260-263. Vidi također: KRISTINA KAPONJA, Antun Reiner - monografska obrada, diplomski rad, Odsjek za povijest umjetnosti Filozofskog fakulteta Sveučilišta u Zagrebu, Zagreb, 2014.

40 O oltarima u Boku i Osekovu vidi: DORIS BARIČEVIĆ, 2008., (bilj. 3), 131, 262.

\section{Summary}

Dubravka Botica, Danko Šourek

ALTARS IN THE PARISH CHURCH OF ST. LADISLAUS IN POKUPSKO - A CONTRIBUTION TO THE TYPOLOGY OF ALTAR ARCHITECTURE IN THE $18^{\text {TH }}$ CENTURY

The main and the side altars of St. Mary and St. Joseph (1739) in the sanctuary and within the vaulted triumphal arch of the parish church in Pokupsko make up a captivating ensemble, with its fine artistic concept, as well as a distinctive iconographic programme. The ensemble, which also includes a pulpit and sculptures from the Altar of the Holy Cross, is part of a large commission by the Zagreb Bishop Juraj Branjug, who had the new church in Pokupsko erected between 1736 and 1739, and dedicated to the bishopric founder, St. Ladislaus the King. The altars were executed by a woodcarving workshop that was active in the Zagreb Kaptol (Chapter) during the first half of the $18^{\text {th }}$ century, under the patronage of the bishop. The altars' architectural schemes and innovative ornamental repertoire tie the contemporary production of northwestern Croatia to the central European artistic tradition, later echoed in the works of other Zagreb artists, such as Josip Weinacht, Antun Reiner and Antun Franjo Risner. The iconographic aspects of the main altar, on the other hand, are associated with the distinctive iconography of St. Ladislaus the King, which evolved in the circle of the Kaptol commissioners in the late $17^{\text {th }}$ and early $18^{\text {th }}$ century.

KEYwords: Pokupsko, Altar of St. Ladislaus, altars of St. Joseph and St. Mary, Bishop Branjug, "Branjug's woodcarving workshop", altar architecture 